\title{
Supplier Selection by Using a Fuzzy Integrated Model for a Textile Company
}

\author{
Alptekin Ulutas \\ Cumhuriyet University \\ 058140 Imaret, Merkez, Sivas, Turkey \\ E-mail.aulutas@cumhuriyet.edu.tr \\ cross'ref $^{\mathrm{http}: / / \mathrm{dx} . \text { doi.org/10.5755/j01.ee.30.5.20546 }}$
}

\begin{abstract}
Supply chain management determining the competitive position of corporations in a rival and fast-changing environment is one of the favourite topics in engineering economics. Since the performance of suppliers affects the performance of the whole supply chain, the selection of a supplier is a significant problem in supply chain management. When solving a supplier selection problem, there are many criteria needed to be considered. Therefore, the supplier selection problem is a multicriteria decision making (MCDM) problem. In the supplier selection process, most of the time, expert data is involved, and the judgement of experts includes ambiguous, imprecise and uncertain data. Thus, there are many methods to solve supplier selection issues by utilising fuzzy set theory, grey theory and rough theory to handle vagueness of a problem. This study also proposes a fuzzy model to solve this problem. In this study, an integrated fuzzy MCDM model including the Fuzzy Analytic Hierarchy Process (FAHP) and the Fuzzy Operational Competitiveness RAting (Fuzzy OCRA) will be proposed to solve supplier selection problem for a Turkish textile company. The FAHP is utilised to determine the weights of considered eight criteria and the fuzzy OCRA is used to rank five fabric suppliers concerning their performances on eight measures. This study is original and it contributes to the literature in two ways: first, this study proposes a fuzzy extension of the OCRA method and second, this study offers a new integrated fuzzy MCDM model consisting of the FAHP and the Fuzzy OCRA. By using a real case study of supplier selection problem, it is attempted to indicate the applicability of the new integrated fuzzy MCDM model for actual circumstances.
\end{abstract}

Keywords: Supplier Selection; Fuzzy; AHP; OCRA; Textile.

\section{Introduction}

Supply chain management (SCM), which determines the global competitive position of companies in a rival and fast-changing environment, is one of the crucial parts of engineering economics. Supplier selection is described as one of the significant problems in SCM as the supplier performance affects the entire supply chain performance. Due to many criteria involving choosing the most appropriate suppliers, supplier selection can be described as MCDM problem (Ho et al., 2010). Choosing suitable suppliers may help to reduce purchasing cost and improve corporate competitiveness. However, working with an inappropriate supplier may lead to an increased risk in finance and operation (Omurca, 2013). Through the process of choosing the best suppliers, it is possible that the company can build a strategic and collaborative partnership with its suppliers. Thus, to achieve advance and development targets of corporations in a competitive market, corporations need to select the most appropriate suppliers and establish profitable and strategic partnerships with them (You et al., 2015).

In supplier selection problem, experts' evaluations related to supplier performance are one of the critical parts of solving this problem. When a human judgement is involved in the evaluation process, uncertainty becomes an indispensable part of the information (Ghorabaee et al., 2017). Any implemented project, its management techniques (Zavadskas et al., 2009), and used technologies (Zavadskas et al., 2013) have impact on risks and environment of projects and is a reason to change risk management strategy and suppliers. In the literature, there are many methods proposed to handle uncertainty in supplier selection problem. Most of the studies considered the fuzzy set theory, grey theory and rough theory to address the uncertainty issue. This paper also proposes a fuzzy integrated model. The aim of developing this fuzzy integrated model is to handle and address uncertainty issues in supplier selection problem. This paper contributes to the literature in two ways: first, this paper presents a fuzzy extension of Operational Competitiveness RAting (Fuzzy OCRA) and second, this paper also proposes a new fuzzy integrated model containing the Fuzzy Analytic Hierarchy Process (FAHP) and the Fuzzy OCRA.

The organization of the paper is as follows. First, a literature review about the application of the FAHP method to address supplier choice problems and an overview of the use of the OCRA method are provided. Next, basic definitions and operations related to fuzzy set theory, the FAHP and the Fuzzy OCRA are indicated in the methodology section. Then, the application of integrated model is presented. Finally, a brief conclusion and future directions are provided.

\section{Literature Review}

Selection among feasible options is a complicated and challenging task, which includes both qualitative and quantitative criteria (Sivilevicius et al., 2008). The use of MCDM techniques can improve the overall sustainability of businesses and organisations, including SCMs (Zavadskas et al., 2016). Recently, many studies have developed 
various integrated sustainability criteria using a variety of MCDM techniques. Dozens of MCDM techniques are available for decision-makers to solve different problems (Rajasekaran et al., 2016). Some of the classical MCDM techniques are as follows; ELECTRE (Benayoun et al., 1966), PROMETHEE (Brans et al., 1986), SAW (MacCrimmon, 1968), REMBRANDT (Olson et al., 1995), SMART (Edwards, 1977), SMARTER (Edwards and Barron, 1994) and QUALIFLEX (Paelinck, 1978). In addition to classical MCDM methods researcher developed dozens of novel methods and their extensions to solve MCDM problems as: COPRAS (Zavadskas \& Kaklauskas, 1996), EDAS (Ghorabaee et al., 2015), CoCoSo (Yazdani et al., 2019), ARAS (Zavadskas \& Turskis, 2010), CODAS (Ghorabaee et al., 2016) and WASPAS (Zavadskas et al., 2012). The extensions of these methods were used to solve MCDM problems (Turskis \& Zavadskas, 2010a; Turskis \& Zavadskas, 2010b; Turskis et al., 2012; Turskis et al., 2015; Zavadskas et al., 2015; Ghorabaee et al., 2016; Ghorabaee et al., 2017). Different ranking results obtained when different MCDM methods applied. Therefore, scientists suggest using of integrated MCDM techniques (Multiplicative Exponential Weighting, Game Theory, SAW, AHP, EDAS, TOPSIS, ARAS, Laplace Rule, Full Multiplicative form, and Bayes Rule) to decide which option is the best (Turskis and Juodagalviene, 2016). Recently, many different MCDM methods are used to solve the supplier selection problem. For example, the best worst method (Rezaei et al., 2016), linguistic MCDM method (Cid-Lopez et al., 2016), fuzzy EDAS (Ghorabaee et al., 2016), TOPSIS-MMD (Aouadni et al., 2017), intuitionistic VIKOR (Zhao et al., 2017), fuzzy Rasch based COPRAS-G (Chatterjee \& Kar, 2018) and neutrosophic DEMATEL (Abdel-Basset et al., 2018). The green supplier selection problem takes into account also environmental factors, unlike the common supplier selection problem. There are also many studies proposed MCDM techniques to solve green supplier selection problem (Hu et al., 2015; Sang and Liu, 2016; Qin et al., 2017; Banaeian et al., 2018).

This section will be divided into two sub-sections, which are the FAHP in supplier selection and the applications of the OCRA method.

\section{FAHP in Supplier Selection}

The supplier selection problems aim to determine suppliers having the top capability to respond to the requirement of enterprises as supplier selection is a noteworthy problem in SCM for several companies (Shahmardan and Zadeh, 2014). Supplier selection problem as most of the MCDM problems depends on human judgment, including vagueness. Most of the authors in the literature proposed models, including fuzzy numbers, rough numbers, and grey numbers etc. to handle the uncertainty in the problem of supplier selection. This section will deal with using the FAHP to select the best supplier among available options. In general, the methods of identifying the attributes' weights divide into two classifications: subjective and objective methods (Li et al., 2015). The first mentioned methods (subjective) are to identify characteristics' weights in terms of decision makers' subjective judgment or preference, comprising AHP (Saaty, 1977; Saaty, 1980; Peng et al., 2011; Ergu et al., 2013; Kou et al., 2014), Delphi method, the direct rating method (Roberts \& Goodwin, 2002) and others. However, both objective and subjective categories have their advantages and disadvantages. Objective methods have a robust theoretical and mathematical basis, and the results of assessment do not depend upon factors of humans, but they do not project decision-makers' subjective preferences and these methods disregard the accumulation of experts' experience and knowledge. To make scientific and accurate judgements, the decision makers are generally needed to assign quantitative or qualitative assessment scores for identifying the relative importance of the assessment criteria and the performance of alternatives. They always are subjective and to determine them, and stakeholders need to know their goals and help of experts. Systematic comparison and measurement of the importance of criteria is the basis for techniques, such as AHP (Saaty, 1977), ANP (Saaty, 1996), SWARA (Kersuliene et al., 2010; Ruzgys et al., 2014) and FARE (Ginevicius, 2011) to determine the relative importance of criteria. Researchers concern about weighting methods for more than fifty years. In 1965, Eckenrode compared efficiency of six methods (two types of Partial Paired Comparisons, Rating, Ranking, Successive Comparisons, and Complete Paired Comparisons) in collecting the judgment data and determined that the values computed by all of the methods correlate (Eckenrode, 1965). Recently, Turskis et al. extended the Eckenrode's rating technique and presented its fuzzy extension (Turskis et al., 2019). The AHP method is the most widely used method among the MCDM methods (Zavadskas et al., 2016). Therefore, the AHP method is verified in many studies and is one of the soundest mathematical techniques to determine criteria weights. The first overview of the AHP method applications presented by Zahedi (Zahedi, 1986). After this study, Vargas (1990) presented the overview of AHP. Also, Ishizaka and Labib (2011) presented the analysis of the main events in the AHP development. Van Laarhoven and Pedrycz published an article on the method's fuzzy extension (Van Laarhoven \& Pedrycz, 1983). The paper by Buckley followed it (Buckley, 1985). FAHP has been preferred by many authors in the literature as it can address uncertainty. However, T. L. Saaty was against use of the fuzzy extension of the AHP and stated that the "Fuzzy set practice had become a self-defeating number crunching enterprise to publish papers."(Saaty, 2006). Contrary to Saaty's paper, scholars use the fuzzy extension of the AHP method. Buckley et al. (2001) and Fedrizzi \& Krejci (2015) argue that the fuzzy extension of the AHP method is valid, and it should be used by decision-makers to solve real-life problems. For solving the problem of supplier selection, the FAHP has been used in the literature many times (Chan et al., 2008; Aydin and Kahraman, 2010; Kilincci and Onal, 2011). Table 1 indicates some recent studies related to the FAHP and its types used to solve supplier selection problem. 
Table 1 OCRA method to select process in manufacturing sector. In

Recent Studies in Literature

\begin{tabular}{|c|c|c|}
\hline Authors & \begin{tabular}{|c|} 
Methods \\
\end{tabular} & Year \\
\hline Ghorbani et al. & $\begin{array}{l}\text { Fuzzy Kano Model, FAHP and Fuzzy } \\
\text { TOPSIS } \\
\text { (Technique for order preference by } \\
\text { similarity to an ideal solution) }\end{array}$ & 2013 \\
\hline Kannan et al. & $\begin{array}{l}\text { FAHP, Fuzzy TOPSIS and Fuzzy Multi- } \\
\text { objective Linear Programming (MOLP) }\end{array}$ & 2013 \\
\hline Alinezad et al. & $\begin{array}{l}\text { Quality Function Deployment (QFD) } \\
\text { and FAHP }\end{array}$ & 2013 \\
\hline Pitchipoo et al. & $\begin{array}{l}\text { FAHP and Grey Relational Analysis } \\
\text { (GRA) }\end{array}$ & 2013 \\
\hline Li et al. & FAHP and Dynamic Programming & 2013 \\
\hline Kaur & Intuitionistic FAHP & 2014 \\
\hline Rezaei et al. & $\begin{array}{l}\text { Conjunctive Screening Method and } \\
\text { FAHP }\end{array}$ & 2014 \\
\hline Junior et al. & FAHP and Fuzzy TOPSIS & 2014 \\
\hline Kahraman et al. & Interval Type 2 FAHP & 2014 \\
\hline Kar & $\begin{array}{l}\text { FAHP and Fuzzy Goal Programming } \\
\text { (FGP) }\end{array}$ & 2014 \\
\hline $\mathrm{Xu}$ and Liao & Intuitionistic FAHP & 2014 \\
\hline Azadnia et al. & FAHP and MOLP & 2015 \\
\hline Lee et al. & FAHP and Fuzzy TOPSIS & 2015 \\
\hline $\begin{array}{l}\text { Gold and } \\
\text { Awasthi }\end{array}$ & FAHP & 2015 \\
\hline $\begin{array}{l}\text { Plebankiewicz } \\
\text { and Kubek }\end{array}$ & AHP and FAHP & 2015 \\
\hline Sultana et al. & $\begin{array}{l}\text { Fuzzy Delphi, FAHP and Fuzzy } \\
\text { TOPSIS }\end{array}$ & 2015 \\
\hline Oztaysi et al. & Hesitant FAHP & 2015 \\
\hline $\begin{array}{l}\text { Yadav and } \\
\text { Sharma }\end{array}$ & FAHP & 2015 \\
\hline Liao et al. & $\begin{array}{l}\text { FAHP, Multi-segment goal } \\
\text { programming and Fuzzy Additive Ratio } \\
\text { Assessment (ARAS) }\end{array}$ & 2016 \\
\hline $\begin{array}{l}\text { Wang Chen et } \\
\text { al. }\end{array}$ & FAHP and Fuzzy TOPSIS & 2016 \\
\hline $\begin{array}{l}\text { Deepika and } \\
\text { Kannan }\end{array}$ & Intuitionistic FAHP & 2016 \\
\hline Ulutas et al. & $\begin{array}{l}\text { FAHP, Fuzzy Complex Proportional } \\
\text { Assessment (Fuzzy COPRAS) and } \\
\text { Fuzzy Linear Programming (FLP) }\end{array}$ & 2016 \\
\hline Asgari et al. & $\begin{array}{l}\text { FAHP, FGP and Adaptive neuro-fuzzy } \\
\text { inference system (ANFIS) }\end{array}$ & 2016 \\
\hline Secundo et al. & FAHP & 2017 \\
\hline Kumar et al. & FAHP and Fuzzy MOLP & 2017 \\
\hline $\begin{array}{l}\text { Tooranloo and } \\
\text { Iranpour }\end{array}$ & Interval-valued Intuitionistic FAHP & 2017 \\
\hline $\begin{array}{l}\text { Buyukozkan } \\
\text { and Gocer }\end{array}$ & $\begin{array}{l}\text { Intuitionistic FAHP and Intuitionistic } \\
\text { Fuzzy Axiomatic Design (FAD) }\end{array}$ & 2017 \\
\hline Zimmer et al. & $\begin{array}{l}\text { Input-Output Analysis, Social Risk } \\
\text { Assessment Model and FAHP }\end{array}$ & 2017 \\
\hline Awasthi et al. & $\begin{array}{l}\text { FAHP and Fuzzy VIKOR } \\
\text { (visekriterijumska optimizacija i } \\
\text { kompromisno resenje) }\end{array}$ & 2018 \\
\hline Wang et al. & $\begin{array}{l}\text { FAHP and Green Data Envelopment } \\
\text { Analysis (DEA) }\end{array}$ & 2018 \\
\hline
\end{tabular}

\section{The Applications of OCRA}

By comparison with other MCDM methods, the OCRA method was less common used to solve MCDM problems in the literature (Stanujkic et al., 2017). The OCRA method, which was developed by Parkan (1994), was used to address some types of MCDM problems. For instance, Parkan (1996) proposed the OCRA method to analyse the hotel operations' performance. In another attempt, Parkan et al. (1997) measured the performance of teams of software development of a bank by using the OCRA method. Additionally, Parkan and $\mathrm{Wu}(1998 ; 2000)$ proposed the another study, Parkan (2003) used the OCRA method to identify the impact of a point of sale system on drugstore's performance. Furthermore, Parkan (2005) proposed the OCRA method to compare two hotels' operational performances. Besides, the OCRA method was utilised to solve different types of MCDM problems such as hotel selection (Isik \& Adali, 2016), material selection (Chatterjee $\&$ Chakraborty, 2012), and performance analysis of public banks (Ozbek, 2015). Additionally, Stanujkic et al. (2017) developed Improved Grey OCRA method to handle uncertainty in MCDM problems. The authors applied this method to contractor selection and capital investment project selection problems.

\section{Methodology}

In this study, the FAHP and the fuzzy OCRA will be utilised to solve supplier selection problem. This section consists of three sub-sections, which are basic definitions and operations, FAHP and fuzzy OCRA.

\section{Basic Definitions and Operations}

Fuzzy set theory has been used to handle information including uncertainty, vagueness and impreciseness in problems in the literature. Some basic concepts and definitions, which are used to develop fuzzy integrated model including the FAHP and the fuzzy OCRA, are stated as follows (Gani and Assarudeen, 2012):

Definition 1. A fuzzy set $\widetilde{D}$ is defined as following equation:

$$
\widetilde{D}=\left\{\left(x, \mu_{D}(x)\right): x \in D, \mu_{D}(x) \in[0,1]\right\}
$$

In equation $1, x \in D$ denotes that elements belonging to the classical set $D$ and $\mu_{D}(x)$ indicates membership function and it belongs to $[0,1]$.

Definition 2. If $\widetilde{D}=\left(l_{D}, m_{D}, u_{D}\right)$ is a fuzzy triangular number, its membership function can be described as follows.

$$
\mu_{\widetilde{D}}(x)=\left\{\begin{array}{cc}
0, & \text { for } x<l_{D} \\
\frac{x-l_{D}}{m_{D}-l_{D}}, & \text { for } l_{D}<x<m_{D} \\
\frac{u_{D}-x}{u_{D}-m_{D}}, & \text { for } m_{D}<x<u_{D} \\
0, & \text { for } x>u_{D}
\end{array}\right\}
$$

Definition 3. Let us assume that $\widetilde{D}=\left(l_{D}, m_{D}, u_{D}\right)$ and $\tilde{E}=\left(l_{E}, m_{E}, u_{E}\right)$ are two positive triangular fuzzy numbers and $z$ is a positive crisp number. The arithmetic operations using these fuzzy numbers and crisp number are indicated below (Van Laarhoven and Pedrycz, 1983).
i. Addition: $\widetilde{D}+\widetilde{E}=\left(l_{D}+l_{E}, m_{D}+m_{D}, u_{D}+u_{E}\right)$
ii. Subtraction: $\widetilde{D}-\widetilde{E}=\left(l_{D}-u_{E}, m_{D}-m_{E}, u_{D}-\right.$ $\left.l_{E}\right)$
iii. Multiplication: $\widetilde{D} \times \widetilde{E}=\left(l_{D} \times l_{E}, m_{D} \times m_{E}, u_{D} \times\right.$ $\left.u_{E}\right)$
iv. Division: $\widetilde{D} / \tilde{E}=\left(l_{D} / u_{D}, m_{D} / m_{E}, u_{D} / l_{E}\right)$
v. Scalar Addition: $\tilde{E}+z=\left(l_{E}+z, m_{E}+z, u_{E}+z\right)$
vi. Scalar Division: $\tilde{E} / z=\left(l_{E} / z, m_{E} / z, u_{E} / z\right)$ 


\section{Fuzzy AHP}

In this study, the FAHP and the fuzzy OCRA will be used to solve supplier selection problem. The FAHP (Calabrese et al., 2013; Ulutas et al., 2016) will be utilised to identify the weights of criteria. Decision makers utilised terms in Table 2 to compare criteria. The FAHP's steps are as follows.

Step 1.1: First of all, the fuzzy judgements of decision makers are aggregated by following equations.

$$
\begin{array}{ll}
l_{i j}=\min _{k}\left(l_{i j}^{1}, l_{i j}^{2}, l_{i j}^{3} \ldots l_{i j}^{k}\right) & i, j=1, \ldots n \\
m_{i j}=\frac{\left(m_{i j}^{1}+m_{i j}^{2}+m_{i j}^{3}+\cdots+m_{i j}^{k}\right)}{k} & i, j=1, \ldots n \\
u_{i j}=\max _{k}\left(u_{i j}^{1}, u_{i j}^{2}, u_{i j}^{3} \ldots u_{i j}^{k}\right) & i, j=1, \ldots n
\end{array}
$$

After the aggregation process, comparison matrix $(\tilde{C})$ is structured to compare criteria.

$$
\tilde{C}=\left(\tilde{c}_{i j}\right)_{n \times n}
$$

where

$$
\tilde{c}_{i j}=\left(l_{i j}, m_{i j}, u_{i j}\right) \text { and } \tilde{c}_{i j}^{-1}=\left(\frac{1}{u_{i j}}, \frac{1}{m_{i j}}, \frac{1}{l_{i j}}\right) i, j=
$$

$1, \ldots n ; i \neq j$

and $u_{i j}, m_{i j}$ and $l_{i j}$ indicate the upper, medium and lower values of $\tilde{c}_{i j}$ respectively.

Table 2

Terms and Fuzzy Scores used in FAHP

\begin{tabular}{|l|c|}
\hline Terms & Fuzzy Scores \\
\hline Absolutely Importance & $(8,9,10)$ \\
\hline Intermediate & $(7,8,9)$ \\
\hline Very Strongly Importance & $(6,7,8)$ \\
\hline Intermediate & $(5,6,7)$ \\
\hline Strong Importance & $(4,5,6)$ \\
\hline Intermediate & $(3,4,5)$ \\
\hline Weakly Importance & $(2,3,4)$ \\
\hline Intermediate & $(1,2,3)$ \\
\hline Equally Importance & $(1,1,1)$ \\
\hline
\end{tabular}

Source: Adapted from Chou and Cheng (2012)

Step 1.2: Comparison matrix $(\tilde{C})$ 's consistency index $(C I)$ and the comparison matrix $(\tilde{C})$ 's consistency ratio $(C R)$ are calculated by using Eqns. 9 and 10 respectively to analyse the consistency of $\tilde{C}$ (Saaty, 1990). If $C R$ of $\tilde{C}$ is less than $0.1, \tilde{C}$ will be accepted as a consistent comparison matrix. Otherwise, the judgements of decision makers will be collected to structure a new comparison matrix. Each element $\left(\tilde{c}_{i j}\right)$ of $\tilde{C}$ need to be transformed into crisp numbers using the centre of gravity method to calculate $C I$ of $\tilde{C}$ (Wang and Elhag, 2007):

$$
c_{i j}=\frac{l_{i j}+m_{i j}+u_{i j}}{3} \quad i, j=1, \ldots n
$$

By using Eq. 9, $C I$ of $\tilde{C}$ is calculated. In this equation, $\beta_{\max }$ denotes the largest eigenvalue of $C$. After calculating of $C I$ value, $C R$ of $C$ can be computed by using equation 10. In this equation, $R I$ represents a random index, which is based on the number of criteria $(n)$. In this study, $R I$ equals to 1,4 due to 8 criteria considered.

$$
\begin{aligned}
& C I=\frac{\left(\beta_{\max }-n\right)}{n-1} \\
& C R=(C I / R I)
\end{aligned}
$$

If comparison matrix $(\tilde{C})$ is consistent, the analysis of $\tilde{C}$ is continued by equation 11 .

Step 1.3: For each row in $\tilde{C}$ is summed to obtain relative row $\operatorname{sum}\left(\widetilde{M}_{i}\right)$ as:

$\widetilde{M}_{i}=\sum_{j=1}^{n} \tilde{c}_{i j}=\left(\sum_{j=1}^{n} l_{i j}, \sum_{j=1}^{n} m_{i j}, \sum_{j=1}^{n} u_{i j}\right) i, j=1, \ldots n$

Step 1.4: To obtain fuzzy weights of $i^{\text {th }}$ criterion $\left(\widetilde{w}_{i}\right)$, the normalisation formula of Wang et al. (2008) is used as:

$$
\begin{gathered}
\widetilde{w}_{i}=\frac{\widetilde{M}_{i}}{\sum_{j=1}^{n} \widetilde{M}_{i}}= \\
\left(\frac{\sum_{j=1}^{n} l_{i j}}{\sum_{j=1}^{n} l_{i j}+\sum_{q=1, q \neq j}^{n} \sum_{j=1}^{n} u_{i j}}, \frac{\sum_{j=1}^{n} m_{i j}}{\sum_{q=1}^{n} \sum_{j=1}^{n} m_{i j}}, \frac{\sum_{j=1}^{n} u_{i j}}{\sum_{j=1}^{n} u_{i j}+\sum_{q=1, q \neq j}^{n} \sum_{j=1}^{n} l_{i j}}\right) \\
=\left(l_{i}, m_{i}, u_{i}\right) \quad i, j=1, \ldots n
\end{gathered}
$$

Step 1.5: Fuzzy weights of $i^{\text {th }}$ criterion $\left(\widetilde{w}_{i}\right)$ are transformed into crisp weight $\left(w_{i}\right)$ of $i^{\text {th }}$ criterion through defuzzification formula (equations 13-16) of $\mathrm{Wu}$ and Lee (2007):

$$
\begin{aligned}
& l_{e}=m_{i} /\left(1+m_{i}-l_{i}\right) i=1,2, \ldots . n \\
& u_{e}=u_{i} /\left(1+u_{i}-m_{i}\right) i=1,2, \ldots . n \\
& z_{e}=\frac{\left(l_{e} \times\left(1-l_{e}\right)\right)+\left(u_{e} \times u_{e}\right)}{\left(1-l_{e}+u_{e}\right)} i=1,2, \ldots . n \\
& w_{i}=\min l_{e}+z_{e} \times \Delta_{\min }^{\max } i=1,2, \ldots . n \\
& \text { where } \Delta_{\min }^{\max }=\max _{e}-\operatorname{minl}_{e} . \\
& \text { Step 1.6: To normalise } w_{i}, \text { equation } 17 \text { is used as: } \\
& w_{i}^{*}=\frac{w_{i}}{\sum_{i=1}^{n} w_{i}} i=1,2, \ldots . n
\end{aligned}
$$

After obtaining normalised crisp weight $\left(w_{i}^{*}\right)$ of $i^{\text {th }}$ criterion, these normalised weights are transferred into fuzzy OCRA.

\section{Fuzzy OCRA}

The Fuzzy OCRA method consisting of seven steps is used to rank alternatives. Decision makers used terms in Table 3 to identify the performance of alternatives with respect to considered criteria. The steps of the Fuzzy OCRA are presented as below.

Step 2.1: First, the fuzzy scores are aggregated by using equations $3-5$ to structure decision matrix $(\tilde{X})$ shown in equation 18 .

$\tilde{X}=\left(\tilde{x}_{s i}\right)_{t \times n} \quad i=1,2, \ldots . n \quad s=1,2, \ldots . t \quad(18)$

In this equation, $\tilde{x}_{s i}$ denotes fuzzy score of the $s^{\text {th }}$ alternative with respect to the $i^{\text {th }}$ criterion.

Table 3

\section{Terms and Fuzzy Scores used in Fuzzy OCRA}

\begin{tabular}{|l|c|}
\hline \multicolumn{1}{|c|}{ Terms } & Fuzzy Scores \\
\hline Perfect & $(8,9,10)$ \\
\hline Very High & $(7,8,9)$ \\
\hline High & $(6,7,8)$ \\
\hline Medium High & $(5,6,7)$ \\
\hline Medium & $(4,5,6)$ \\
\hline Medium Low & $(3,4,5)$ \\
\hline Low & $(2,3,4)$ \\
\hline Very Low & $(1,2,3)$ \\
\hline Equal & $(1,1,1)$ \\
\hline
\end{tabular}

Source: Adapted from Fouladgar et al. (2012)

Step 2.2: Fuzzy performance ratings in accordance with non-beneficial criteria are aggregated by following equation 19.

$$
\tilde{\bar{I}}_{s}=\sum_{i \in \Omega_{\min }} w_{i}^{*} \frac{\max _{i} \tilde{x}_{s i}-\tilde{x}_{s i}}{\min _{i} \tilde{x}_{s i}}
$$


where $\tilde{\bar{I}}_{s}$ represents the aggregate fuzzy performance rating of the $s^{\text {th }}$ alternative calculated based on the nonbeneficial criteria.

Step 2.3: Fuzzy linear performance rating of each alternative considered the non-beneficial criteria are evaluated by using following equation.

$$
\tilde{\overline{\bar{I}}}_{s}=\tilde{\bar{I}}_{s}-\min _{s} \tilde{\bar{I}}_{s}
$$

where $\tilde{\bar{I}}_{S}$ denotes the fuzzy linear performance rating of the $s^{\text {th }}$ alternative, calculated based on the non-beneficial criteria.

Step 2.4: Fuzzy performance ratings for the beneficial criteria are aggregated by using following equation.

$\widetilde{\bar{O}}_{s}=\sum_{i \in \Omega_{\max }} w_{i}^{*} \frac{\tilde{x}_{s i}-\min _{i} \tilde{x}_{s i}}{\min _{i} \tilde{x}_{s i}}$

where $\widetilde{\bar{O}}_{s}$ is the aggregate fuzzy performance rating of the $s^{\text {th }}$ alternative calculated based on the beneficial criteria.

Step 2.5: Fuzzy linear performance rating of each alternative in accordance with the beneficial criteria are calculated by equation 22 .

$$
\tilde{\overline{\bar{O}}}_{s}=\widetilde{\bar{O}}_{s}-\min _{s} \widetilde{\bar{O}}_{s}
$$

In equation $22, \widetilde{\overline{\bar{O}}}_{s}$ presents the fuzzy linear performance rating of the $s^{\text {th }}$ alternative, calculated according to the beneficial criteria.

Step 2.6: Fuzzy overall performance rating for each alternative is obtained by using equation 23 .

$\tilde{P}_{s}=\tilde{\overline{\bar{I}}}_{s}+\tilde{\overline{\bar{O}}}_{s}-\min \left(\tilde{\overline{\bar{I}}}_{s}+\tilde{\overline{\bar{O}}}_{s}\right) i=1,2, \ldots . n s=1,2, \ldots . t$ where $\tilde{P}_{S}$ denotes fuzzy overall performance rating of $S^{\text {th }}$ alternative.

Step 2.7: In the last step, fuzzy overall performance ratings are converted into crisp overall performance ratings $\left(P_{S}\right)$ by using equation 8 . After obtaining crisp overall performance ratings, alternatives are ranked with respect to these ratings. Alternative having the highest rating is selected as the most appropriate alternative. Next section will present application of the fuzzy integrated model.

\section{Application}

The fuzzy integrated model applied into a Turkish textile company having more than 15 years of experience in shirt manufacturing market. All fuzzy data were collected by using questionnaires from four managers (factory manager, quality manager, purchasing manager and financial manager) of company. The criteria that were considered in the study were decided with the help of consultation conducted with the managers. After consultation, eight criteria were identified for the supplier selection process. These criteria are Quality (C1), Delivery (C2), Technological Capability (C3), Reputation (C4), Cost (C5), Communication Issues (C6), Technical Assistances (C7) and Volume Flexibility (C8). This company purchases fabric used for producing shirts from five suppliers. The aggregated fuzzy scores of criteria (for FAHP) obtained by using equations 3-5 are indicated in Table 4.

Table 4

Aggregated Fuzzy Scores of Criteria (FAHP)

\begin{tabular}{|c|c|c|c|c|}
\hline Criteria & C1 & $\mathbf{C 2}$ & $\mathbf{C 3}$ & $\mathbf{C 4}$ \\
\hline C1 & $(1,1,1)$ & $(1.5,2.25,3)$ & $(4,5,6)$ & $(4.75,5.75,6.75)$ \\
\hline C2 & $(0.333,0.444,0,667)$ & $(1,1,1)$ & $(3.5,4.5,5.5)$ & $(4.5,5.5,6.5)$ \\
\hline C3 & $(0.167,0.2,0.25)$ & $(0.182,0.222,0.286)$ & $(1,1,1)$ & $(1.5,2.5,3,5)$ \\
\hline C4 & $(0.148,0.174,0.211)$ & $(0.154,0.182,0.222)$ & $(0.286,0.4,0.667)$ & $(1,1,1)$ \\
\hline C5 & $(0.667,0.8,1)$ & $(1,1,1)$ & $(4.75,5.75,6.75)$ & $(0.182,0.222,0.286)$ \\
\hline C6 & $(0.138,0.16,0.19)$ & $(0.16,0.19,0.235)$ & $(0.2,0.25,0.333)$ & $(0.667,0.8,1)$ \\
\hline C7 & $(0.16,0.19,0.235)$ & $(0.143,0.167,0.2)$ & $(0.174,0.211,0.267)$ & $(0.5,0.667,1)$ \\
\hline C8 & $(0.154,0.182,0.222)$ & $(0.133,0.154,0.182)$ & $(0.222,0.286,0.4)$ & C8 \\
\hline Criteria & $\mathbf{C 5}$ & $\mathbf{C 6}$ & $\mathbf{C} 7$ & $(4.5,5.5,6.5)$ \\
\hline Criteria & $(1,1.25,1.5)$ & $(5.25,6.25,7.25)$ & $(4.25,5.25,6.25)$ & $(5.5,6.5,7.5)$ \\
\hline C1 & $(1,1,1)$ & $(4.25,5.25,6.25)$ & $(5,6,7)$ & $(2.5,3.5,4.5)$ \\
\hline C2 & $(0.148,0.174,0.211)$ & $(3,4,5)$ & $(3.75,4.75,5.75)$ & $(1,1.5,2)$ \\
\hline C4 & $(0.138,0.16,0.19)$ & $(3.5,4.5,5.5)$ & $(1,1.25,1.5)$ & $(5.25,6.25,7.25)$ \\
\hline C5 & $(1,1,1)$ & $(5.5,6.5,7.5)$ & $(5.5,6.5,7.5)$ & $(1,2,3)$ \\
\hline C6 & $(0.133,0.154,0.182)$ & $(1,1,1)$ & $(1,1.25,1.5)$ & $(2,3,4)$ \\
\hline C7 & $(0.133,0.154,0.182)$ & $(0.667,0.8,1)$ & $(1,1,1)$ & $(1,1,1)$ \\
\hline
\end{tabular}

Aggregated fuzzy scores are analysed with the FAHP to obtain normalised weights of criteria $\left(w_{i}^{*}\right)$. Table 5 presents the normalised weights of criteria. According to Table 5, the order of criteria with respect to their weights are $\mathrm{C} 5>\mathrm{C} 1>$ $\mathrm{C} 2>\mathrm{C} 3>\mathrm{C} 4>\mathrm{C} 7>\mathrm{C} 6>\mathrm{C} 8$. After obtaining the weights of criteria, performance of suppliers are calculated by using the Fuzzy OCRA. Table 6 shows that the aggregated fuzzy scores for the Fuzzy OCRA.

Table 5

The Normalised Weights of Criteria

\begin{tabular}{|c|c|}
\hline Criteria & Weights \\
\hline C1 & 0.190 \\
\hline C2 & 0.182 \\
\hline C3 & 0.122 \\
\hline C4 & 0.091 \\
\hline C5 & 0.198 \\
\hline C6 & 0.074 \\
\hline C7 & 0.078 \\
\hline C8 & 0.065 \\
\hline
\end{tabular}


The Aggregated Fuzzy Scores for Fuzzy OCRA

\begin{tabular}{|c|c|c|c|c|}
\hline $\begin{array}{ll}\text { Suppliers } & \text { Criteria } \\
\end{array}$ & $\mathrm{C} 1$ & $\mathrm{C} 2$ & $\mathrm{C3}$ & $\mathrm{C} 4$ \\
\hline S1 & $(4.75,5.75,6.75)$ & $(5.5,6.5,7.5)$ & $(5,6,7)$ & $(3.75,4.75,5.75)$ \\
\hline $\mathrm{S} 2$ & $(3.75,4.75,5.75)$ & $(4.5,5.5,6.5)$ & $(4.25,5.25,6.25)$ & $(5.75,6.75,7.75)$ \\
\hline S3 & $(4.5,5.5,6.5)$ & $(4.75,5.75,6.75)$ & $(4.75,5.75,6.75)$ & $(4.25,5.25,6.25)$ \\
\hline S4 & $(3,4,5)$ & $(4.25,5.25,6.25)$ & $(3.5,4.5,5.5)$ & $(3,4,5)$ \\
\hline S5 & $(5,6,7)$ & $(3,4,5)$ & $(4.5,5.5,6.5)$ & $(3.25,4.25,5.25)$ \\
\hline $\begin{array}{ll}\text { Suppliers } & \text { Criteria } \\
\end{array}$ & C5 & C6 & C7 & C8 \\
\hline $\mathrm{S} 1$ & $(1.25,2.25,3.25)$ & $(1,2,3)$ & $(4.75,5.75,6.75)$ & $(5,6,7)$ \\
\hline S2 & $(1.5,2.5,3.5)$ & $(1.75,2.75,3.75)$ & $(4.5,5.5,6.5)$ & $(5.25,6.25,7.25)$ \\
\hline S3 & $(1,2,3)$ & $(1.75,2.75,3.75)$ & $(4,5,6)$ & $(5.75,6.75,7.75)$ \\
\hline S4 & $(2,3,4)$ & $(1.5,2.5,3.5)$ & $(4.75,5.75,6.75)$ & $(5.25,6.25,7.25)$ \\
\hline S5 & $(1.75,2.75,3.75)$ & $(1.25,2.25,3.25)$ & $(4.5,5.5,6.5)$ & $(5.5,6.5,7.5)$ \\
\hline
\end{tabular}

Aggregated fuzzy scores are analysed with the Fuzzy OCRA to rank suppliers with respect to their performances in criteria. Table 7 presents the results of the Fuzzy OCRA. According to Table 7, S1 having the highest crisp overall performance rating $\left(P_{S}\right)$ is the best supplier and this is followed by S3, S2, S5 and S4 respectively.

The Results of Fuzzy OCRA

\begin{tabular}{|c|c|c|c|}
\hline $\begin{array}{ll}\text { Suppliers } & \text { Results } \\
\end{array}$ & $\tilde{\bar{I}}_{s}$ & $\tilde{\overline{\bar{I}}}_{s}$ & $\tilde{\overline{\boldsymbol{O}}}_{s}$ \\
\hline S1 & $(-0.060,0.266,0.796)$ & $(-0.597,0.195,1.013)$ & $(-0.113,0.102,0.748)$ \\
\hline S2 & $(-0.115,0.197,0.705)$ & $(-0.652,0.126,0.922)$ & $(-0.148,0.050,0.643)$ \\
\hline S3 & $(-0.096,0.221,0.736)$ & $(-0.633,0.150,0.953)$ & $(-0.115,0.099,0.742)$ \\
\hline S4 & $(-0.217,0.071,0.537)$ & $(-0.754,0,0.754)$ & $(-0.175,0.009,0.563)$ \\
\hline S5 & $(-0.160,0.141,0.629)$ & $(-0.697,0.070,0.846)$ & $(-0.152,0.043,0.631)$ \\
\hline $\begin{array}{ll}\text { Suppliers } & \text { Results } \\
\end{array}$ & 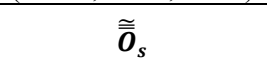 & $\widetilde{\boldsymbol{P}}_{s}$ & $P_{s}$ \\
\hline S1 & $(-0.676,0.093,0.923)$ & $(-2.765,0.288,3.428)$ & 0.317 \\
\hline S2 & $(-0.711,0.041,0.818)$ & $(-2.855,0.167,3.232)$ & 0.181 \\
\hline S3 & $(-0.678,0.090,0.917)$ & $(-2.803,0.240,3.362)$ & 0.266 \\
\hline S4 & $(-0.738,0,0.738)$ & $(-2.984,0,2.984)$ & 0 \\
\hline S5 & $(-0.715,0.034,0.806)$ & $(-2.904,0.104,3.144)$ & 0.115 \\
\hline
\end{tabular}

\section{Conclusion}

Working with inappropriate suppliers can lead a decrease in the performance of entire supply chain as suppliers' performance affect entire supply chain performance. Thus, supplier selection is a significant problem. As several criteria are considered in the supplier selection, this problem is called an MCDM problem. In this study, a new integrated fuzzy MCDM model including the FAHP and the Fuzzy OCRA proposed to handle and solve supplier selection problem for a Turkish textile company. A real case study of this problem is utilised to indicate the practical applicability of integrated fuzzy MCDM model. The FAHP is utilised to obtain the weights of criteria considered and the Fuzzy OCRA is used to rank suppliers. Supplier 1 (S1) is selected as the most appropriate supplier according to the results of proposed model. This paper contributes the literature in two ways: first, this paper presents fuzzy extension of OCRA (Fuzzy OCRA) and second, this paper also proposes a new fuzzy integrated model including the FAHP and the Fuzzy OCRA. Future studies can use the Fuzzy OCRA to handle other MCDM problems, such as warehouse location selection, third party logistics provider selection and machine selection etc.

\section{References}

Abdel-Basset, M., Manogaran, G., Gamal, A., \& Smarandache, F. (2018). A hybrid approach of neutrosophic sets and DEMATEL method for developing supplier selection criteria. Design Automation for Embedded Systems, 1-22. https://doi.org/10.1007/s10617-018-9203-6

Alinezad, A., Seif, A., \& Esfandiari, N. (2013). Supplier evaluation and selection with QFD and FAHP in a pharmaceutical company. The International Journal of Advanced Manufacturing Technology, 68(1/4), 355-364. https://doi.org/10. 1007/s00170-013-4733-3

Aouadni, S., Rebai, A., \& Turskis, Z. (2017). The Meaningful Mixed Data TOPSIS (TOPSIS-MMD) Method and its Application in Supplier Selection. Studies in Informatics and Control, 26(3), 353-363. https://doi.org/10.24846/ v26i3y 201711

Asgari, M. S., Abbasi, A., \& Alimohamadlou, M. (2016). Comparison of ANFIS and FAHP-FGP methods for supplier selection. Kybernetes, 45(3), 474-489. https://doi.org/10.1108/K-09-2014-0195 
Awasthi, A., Govindan, K., \& Gold, S. (2018). Multi-tier sustainable global supplier selection using a fuzzy AHP-VIKOR based approach. International Journal of Production Economics, 195, 106-117. https://doi.org/10.1016/j.ijpe. 2017.10.013

Aydin, S., \& Kahraman, C. (2010). Multiattribute supplier selection using fuzzy analytic hierarchy process. International Journal of Computational Intelligence Systems, 3(5), 553-565. https://doi.org/10.2991/ijcis.2010.3.5.5

Azadnia, A. H., Saman, M. Z. M., \& Wong, K. Y. (2015). Sustainable supplier selection and order lot-sizing: an integrated multi-objective decision-making process. International Journal of Production Research, 53(2), 383-408. https://doi.org/10.1080/00207543.2014.935827

Banaeian, N., Mobli, H., Fahimnia, B., Nielsen, I. E., \& Omid, M. (2018). Green supplier selection using fuzzy group decision making methods: A case study from the agri-food industry. Computers \& Operations Research, 89, $337-347$. https://doi.org/10.1016/j.cor.2016.02.015

Benayoun, R., Roy, B., \& Sussman, B. (1966). ELECTRE: Une méthode pour guider le choix en présence de points de vue multiples. Note de Travail, 49.

Brans, J. P., Vincke, P., \& Mareschal, B. (1986). How to select and how to rank projects: The PROMETHEE method. European Journal of Operational Research, 24(2), 228-238. https://doi.org/10.1016/0377-2217(86)90044-5

Buckley, J. J. (1985). Fuzzy hierarchical analysis. Fuzzy Sets and Systems, 17(3), 233-247. https://doi.org/10.1016/01650114(85)90090-9

Buckley, J. J., Feuring, T., \& Hayashi, Y. (2001). Fuzzy hierarchical analysis revisited. European Journal of Operational Research, 129(1), 48-64. https://doi.org/10.1016/S0377-2217(99)00405-1

Buyukozkan, G., \& Gocer, F. (2017). Application of a new combined intuitionistic fuzzy MCDM approach based on axiomatic design methodology for the supplier selection problem. Applied Soft Computing, 52, $1222-1238$. https://doi.org/10.1016/j.asoc.2016.08.051

Calabrese, A., Costa, R., \& Menichini, T. (2013). Using Fuzzy AHP to manage Intellectual Capital assets: An application to the ICT service industry. Expert Systems with Applications, 40(9), 3747-3755. https://doi.org/10.1016/ j.eswa.2012.12.081

Chan, F. T., Kumar, N., Tiwari, M. K., Lau, H. C., \& Choy, K. L. (2008). Global supplier selection: a fuzzy-AHP approach. International Journal of Production Research, 46(14), 3825-3857. https://doi.org/10.1080/00207540600787200

Chatterjee, P., \& Chakraborty, S. (2012). Material selection using preferential ranking methods. Materials \& Design, 35, 384-393. https://doi.org/10.1016/j.matdes.2011.09.027

Chatterjee, K., \& Kar, S. (2018). Supplier selection in Telecom supply chain management: a Fuzzy-Rasch based COPRASG method. Technological and Economic Development of Economy, 24(2), 765-791. https://doi.org/10.3846/20 294913.2017.1295289

Chou, W. C., \& Cheng, Y. P. (2012). A hybrid fuzzy MCDM approach for evaluating website quality of professional accounting firms. Expert Systems with Applications, 39(3), 2783-2793. https://doi.org/10.1016/j.eswa.2011.08.138

Cid-Lopez, A., Hornos, M. J., Carrasco, R. A., \& Herrera-Viedma, E. (2016). Applying a linguistic multi-criteria decisionmaking model to the analysis of ICT suppliers' offers. Expert Systems with Applications, 57, $127-138$. https://doi.org/10.1016/j.eswa.2016.03.025

Deepika, M., \& Kannan, A. K. (2016, March). Global supplier selection using intuitionistic fuzzy analytic hierarchy process. In Electrical, Electronics, and Optimization Techniques (ICEEOT), International Conference on (pp. 2390-2395). IEEE. https://doi.org/10.1109/ICEEOT.2016.7755122

Eckenrode, R. T. (1965). Weighting multiple criteria. Management Science, 12(3), 180-192. https://doi.org/10.1287/ mnsc.12.3.180

Edwards, W. (1977). How to use multiattribute utility measurement for social decisionmaking. IEEE Transactions on Systems, Man, and Cybernetics, 7(5), 326-340. https://doi.org/10.1109/TSMC.1977.4309720

Edwards, W., \& Barron, F. H. (1994). SMARTS and SMARTER: Improved simple methods for multiattribute utility measurement. Organizational Behavior and Human Decision Processes, 60(3), 306-325. https://doi.org/10.1006/ obhd.1994.1087

Ergu, D., Kou, G., Peng, Y., Shi, Y., \& Shi, Y. (2013). The analytic hierarchy process: task scheduling and resource allocation in cloud computing environment. The Journal of Supercomputing, 64(3), 835-848. https://doi.org/10. $1007 / \mathrm{s} 11227-011-0625-1$

Fedrizzi, M., \& Krejcí, J. (2015). A note on the paper "fuzzy analytic hierarchy process: Fallacy of the popular methods". International Journal of Uncertainty, Fuzziness and Knowledge-Based Systems, 23(06), 965-970. https://doi.org/10. 1142/S0218488515500440 
Fouladgar, M. M., Yazdani-Chamzini, A., Lashgari, A., Zavadskas, E. K., \& Turskis, Z. (2012). Maintenance strategy selection using AHP and COPRAS under fuzzy environment. International Journal of Strategic Property Management, 16(1), 85-104. https://doi.org/10.3846/1648715X.2012.666657

Gani, A. N., \& Assarudeen, S. M. (2012). A new operation on triangular fuzzy number for solving fuzzy linear programming problem. Applied Mathematical Sciences, 6(11), 525-532.

Ghorabaee, M.K., Zavadskas, E. K., Olfat, L., \& Turskis, Z. (2015). Multi-criteria inventory classification using a new method of evaluation based on distance from average solution (EDAS). Informatica, 26(3), 435-451. https://doi.org/10.15388/Informatica.2015.57

Ghorabaee, M. K., Zavadskas, E. K., Amiri, M., \& Turskis, Z. (2016). Extended EDAS method for fuzzy multi-criteria decision-making: an application to supplier selection. International Journal of Computers Communications \& Control, 11(3), 358-371. https://doi.org/10.15837/ijccc.2016.3.2557

Ghorabaee, M.K., Zavadskas, E. K., Turskis, Z., \& Antucheviciene, J. (2016). A New Combinative Distance-Based Assessment (Codas) Method For Multi-Criteria Decision-Making. Economic Computation \& Economic Cybernetics Studies \& Research, 50(3), 25-44.

Ghorabaee, M.K., Amiri, M., Zavadskas, E. K., Turskis, Z., \& Antucheviciene, J. (2017). Stochastic EDAS method for multi-criteria decision-making with normally distributed data. Journal of Intelligent \& Fuzzy Systems, 33(3), 16271638.https://doi.org/10.3233/JIFS-17184

Ghorabaee, M.K., Amiri, M., Zavadskas, E. K., \& Antucheviciene, J. (2017). Supplier evaluation and selection in fuzzy environments: a review of MADM approaches. Economic Research-Ekonomska Istrazivanja, 30(1), 1073-1118. https://doi.org/10.1080/1331677X.2017.1314828

Ghorbani, M., Mohammad Arabzad, S., \& Shahin, A. (2013). A novel approach for supplier selection based on the Kano model and fuzzy MCDM. International Journal of Production Research, 51(18), 5469-5484. https://doi.org/10.1080/00207543.2013.784403

Ginevicius, R. (2011). A new determining method for the criteria weights in multicriteria evaluation. International Journal of Information Technology \& Decision Making, 10(06), 1067-1095. https://doi.org/10.1142/S0219622011004713

Gold, S., \& Awasthi, A. (2015). Sustainable global supplier selection extended towards sustainability risks from (1+ n) th tier suppliers using fuzzy AHP based approach. Ifac-Papersonline, 48(3), 966-971. https://doi.org/10.10 16/j.ifacol.2015.06.208

Ho, W., Xu, X., \& Dey, P. K. (2010). Multi-criteria decision making approaches for supplier evaluation and selection: A literature review. European Journal of Operational Research, 202(1), 16-24. https://doi.org/10.1016/j. ejor.2009.05.009

Hu, Z., Rao, C., Zheng, Y., \& Huang, D. (2015). Optimization decision of supplier selection in green procurement under the mode of low carbon economy. International Journal of Computational Intelligence Systems, 8(3), $407-421$. https://doi.org/10.1080/18756891.2015.1017375

Ishizaka, A., \& Labib, A. (2011). Review of the main developments in the analytic hierarchy process. Expert Systems with Applications, 38(11), 14336-14345. https://doi.org/10.1016/j.eswa.2011.04.143

Isik, A. T., \& Adali, E. A. (2016). A new integrated decision making approach based on SWARA and OCRA methods for the hotel selection problem. International Journal of Advanced Operations Management, 8(2), $140-151$. https://doi.org/10.1504/IJAOM.2016.079681

Junior, F. R. L., Osiro, L., \& Carpinetti, L. C. R. (2014). A comparison between Fuzzy AHP and Fuzzy TOPSIS methods to supplier selection. Applied Soft Computing, 21, 194-209. https://doi.org/10.1016/j.asoc.2014.03.014

Kahraman, C., Oztaysi, B., Sar1, I. U., \& Turanoglu, E. (2014). Fuzzy analytic hierarchy process with interval type-2 fuzzy sets. Knowledge-Based Systems, 59, 48-57. https://doi.org/10.1016/j.knosys.2014.02.001

Kannan, D., Khodaverdi, R., Olfat, L., Jafarian, A., \& Diabat, A. (2013). Integrated fuzzy multi criteria decision making method and multi-objective programming approach for supplier selection and order allocation in a green supply chain. Journal of Cleaner Production, 47, 355-367. https://doi.org/10.1016/j.jclepro.2013.02.010

Kar, A. K. (2014). Revisiting the supplier selection problem: An integrated approach for group decision support. Expert Systems with Applications, 41(6), 2762-2771. https://doi.org/10.1016/j.eswa.2013.10.009

Kaur, P. (2014). Selection of vendor based on intuitionistic fuzzy analytical hierarchy process. Advances in Operations Research, 2014. Article ID: 987690 . https://doi.org/10.1155/2014/987690

Kersuliene, V., Zavadskas, E. K., \& Turskis, Z. (2010). Selection of rational dispute resolution method by applying new step-wise weight assessment ratio analysis (SWARA). Journal of Business Economics and Management, 11(2), 243258. https://doi.org/10.3846/jbem.2010.12 
Kilincci, O., \& Onal, S. A. (2011). Fuzzy AHP approach for supplier selection in a washing machine company. Expert Systems with Applications, 38(8), 9656-9664. https://doi.org/10.1016/j.eswa.2011.01.159

Kou, G., Ergu, D., \& Shi, Y. (2014). An integrated expert system for fast disaster assessment. Computers \& Operations Research, 42, 95-107. https://doi.org/10.1016/j.cor.2012.10.003

Kumar, D., Rahman, Z., \& Chan, F. T. (2017). A fuzzy AHP and fuzzy multi-objective linear programming model for order allocation in a sustainable supply chain: A case study. International Journal of Computer Integrated Manufacturing, 30(6), 535-551. https://doi.org/10.1080/0951192X.2016.1145813

Lee, J., Cho, H., \& Kim, Y. S. (2015). Assessing business impacts of agility criterion and order allocation strategy in multicriteria supplier selection. Expert Systems with Applications, 42(3), 1136-1148. https://doi.org/10.1016/j.eswa. 2014.08.041

Li, Z., Wong, W. K., \& Kwong, C. K. (2013). An integrated model of material supplier selection and order allocation using fuzzy extended AHP and multiobjective programming. Mathematical Problems in Engineering, 2013. https://doi.org/10.1155/2013/363718

Li, G., Kou, G., \& Peng, Y. (2015). Dynamic fuzzy multiple criteria decision making for performance evaluation. Technological and Economic Development of Economy, 21(5), 705-719. https://doi.org/10.3846/20294913. 2015.1056280

Liao, C. N., Fu, Y. K., \& Wu, L. C. (2016). Integrated FAHP, ARAS-F and MSGP methods for green supplier evaluation and selection. Technological and Economic Development of Economy, 22(5), 651-669. https://doi.org/10.3846/2029 4913.2015.1072750

MacCrimmon, K. R. (1968). Decisionmaking among multiple-attribute alternatives: a survey and consolidated approach (No. RM-4823-ARPA). Rand Corp. Santa Monica Calif.

Omurca, S. I. (2013). An intelligent supplier evaluation, selection and development system. Applied Soft Computing, 13(1), 690-697. https://doi.org/10.1016/j.asoc.2012.08.008

Olson, D. L., Fliedner, G., \& Currie, K. (1995). Comparison of the REMBRANDT system with analytic hierarchy process. European Journal of Operational Research, 82(3), 522-539. https://doi.org/10.1016/0377-2217(93)E0340-4

Ozbek, A. (2015). Performance analysis of public banks in Turkey. International Journal of Business Management and Economic Research (IJBMER), 6(3), 178-186.

Oztaysi, B., Onar, S. C., Bolturk, E., \& Kahraman, C. (2015, August). Hesitant fuzzy analytic hierarchy process. In Fuzzy Systems (FUZZ-IEEE), 2015 IEEE International Conference on(pp. 1-7). IEEE. https://doi.org/10.1109/FUZZIEEE.2015.7337948

Paelinck, J. H. (1978). Qualiflex: a flexible multiple-criteria method. Economics Letters, 1(3), 193-197. https://doi.org/10. 1016/0165-1765(78)90023-X

Parkan, C. (1994). Operational competitiveness ratings of production units. Managerial and Decision Economics, 15(3), 201-221. https://doi.org/10.1002/mde.4090150303

Parkan, C. (1996). Measuring the performance of hotel operations. Socio-Economic Planning Sciences, 30(4), $257-292$. https://doi.org/10.1016/S0038-0121(96)00013-4

Parkan, C., Lam, K., \& Hang, G. (1997). Operational competitiveness analysis on software development. Journal of the Operational Research Society, 48(9), 892-905. https://doi.org/10.1057/palgrave.jors.2600446

Parkan, C., \& Wu, M. L. (1998). Process selection with multiple objective and subjective attributes. Production Planning \& Control, 9(2), 189-200. https://doi.org/10.1080/095372898234415

Parkan, C., \& Wu, M. L. (2000). Comparison of three modern multicriteria decision-making tools. International Journal of Systems Science, 31(4), 497-517. https://doi.org/10.1080/002077200291082

Parkan, C. (2003). Measuring the effect of a new point of sale system on the performance of drugstore operations. Computers \& Operations Research, 30(5), 729-744. https://doi.org/10.1016/S0305-0548(02)00047-3

Parkan, C. (2005). Benchmarking operational performance: the case of two hotels. International Journal of Productivity and Performance Management, 54(8), 679-696. https://doi.org/10.1108/17410400510627525

Peng, Y., Kou, G., Wang, G., Wu, W., \& Shi, Y. (2011). Ensemble of software defect predictors: an AHP-based evaluation method. International Journal of Information Technology \& Decision Making, 10(1), 187-206. https://doi.org/10.1142 /S0219622011004282

Pitchipoo, P., Venkumar, P., \& Rajakarunakaran, S. (2013). Fuzzy hybrid decision model for supplier evaluation and selection. International Journal of Production Research, 51(13), 3903-3919. https://doi.org/10.1080/0020 7543.2012 .756592 
Plebankiewicz, E., \& Kubek, D. (2015). Multicriteria selection of the building material supplier using AHP and fuzzy AHP. Journal of Construction Engineering and Management, 142(1), Article Number: 04015057. https://doi.org/10.1061/ (ASCE)CO.1943-7862.0001033

Qin, J., Liu, X., \& Pedrycz, W. (2017). A multiple attribute interval type-2 fuzzy group decision making and its application to supplier selection with extended LINMAP method. Soft Computing, 21(12), 3207-3226. https://doi.org/10.1007/s00 500-015-2004-y

Rajasekaran, K. G., Bhaskar, G. B., Chandrasekaran, M., \& Murali, S. (2016). A Review on Employing Multi Criteria Decision Making Methods for Supplier Selection. Asian Journal of Research in Social Sciences and Humanities, 6(6), 802-810. https://doi.org/10.5958/2249-7315.2016.00245.8

Rezaei, J., Fahim, P. B., \& Tavasszy, L. (2014). Supplier selection in the airline retail industry using a funnel methodology: Conjunctive screening method and fuzzy AHP. Expert Systems with Applications, 41(18), 8165-8179. https://doi.org/10.1016/j.eswa.2014.07.005

Rezaei, J., Nispeling, T., Sarkis, J., \& Tavasszy, L. (2016). A supplier selection life cycle approach integrating traditional and environmental criteria using the best worst method. Journal of Cleaner Production, 135, 577-588. https://doi.org/10.1016/j.jclepro.2016.06.125

Roberts, R., \& Goodwin, P. (2002). Weight approximations in multi-attribute decision models. Journal of Multi-Criteria Decision Analysis, 11(6), 291-303. https://doi.org/10.1002/mcda.320

Ruzgys, A., Volvaciovas, R., Ignatavicius, C., \& Turskis, Z. (2014). Integrated evaluation of external wall insulation in residential buildings using SWARA-TODIM MCDM method. Journal of Civil Engineering and Management, 20(1), 103-110. https://doi.org/10.3846/13923730.2013.843585

Saaty, T. L. (1977). A scaling method for priorities in hierarchical structures. Journal of Mathematical Psychology, 15(3), 234-281. https://doi.org/10.1016/0022-2496(77)90033-5

Saaty, T. L. (1980). The Analytical Hierarchy Process. McGraw-Hill, New York. https://doi.org/10.21236/ADA214804

Saaty, T. L. (1990). How to make a decision: the analytic hierarchy process. European Journal of Operational Research, 48(1), 9-26. https://doi.org/10.1016/0377-2217(90)90057-I

Saaty, T. L. (1996). Decision making with dependence and feedback: The analytic network process. Pittsburgh, Pennsylvania: RWS Publications.

Saaty, T. L. (2006). There is no mathematical validity for using fuzzy number crunching in the analytic hierarchy process. Journal of Systems Science and Systems Engineering, 15(4), 457-464. https://doi.org/10.1007/s11518-006-5021-7

Sang, X., \& Liu, X. (2016). An interval type-2 fuzzy sets-based TODIM method and its application to green supplier selection. Journal of the Operational Research Society, 67(5), 722-734. https://doi.org/10.1057/jors.2015.86

Secundo, G., Magarielli, D., Esposito, E., \& Passiante, G. (2017). Supporting decision-making in service supplier selection using a hybrid fuzzy extended AHP approach: A case study. Business Process Management Journal, 23(1), $196-222$. https://doi.org/10.1108/BPMJ-01-2016-0013

Shahmardan, A., \& Zadeh, M. H. (2014). New Integrated Approach for Solving a Supplier Selection Problem in a Competitive Environment. Inzinerine Ekonomika-Engineering Economics, 25(3), 310-319. https://doi.org/10.575 5/j01.ee.25.3.5092

Sivilevicius, H., Zavadskas, E. K., \& Turskis, Z. (2008). Quality Attributes and Complex Assessment Methodology of the Asphalt Mixing Plant. The Baltic Journal of Road and Bridge Engineering, 3(3), $161-166$. https://doi.org/10.3846/1822-427X.2008.3.161-166

Stanujkic, D., Zavadskas, E. K., Liu, S., Karabasevic, D., \& Popovic, G. (2017). Improved OCRA Method Based on the Use of Interval Grey Numbers. Journal of Grey System, 29(4). https://doi.org/10.24846/v26i1y201701

Sultana, I., Ahmed, I., \& Azeem, A. (2015). An integrated approach for multiple criteria supplier selection combining Fuzzy Delphi, Fuzzy AHP \& Fuzzy TOPSIS. Journal of Intelligent \& Fuzzy Systems, 29(4), $1273-1287$. https://doi.org/10.3233/IFS-141216

Tooranloo, H. S., \& Iranpour, A. (2017). Supplier selection and evaluation using interval-valued intuitionistic fuzzy AHP method. International Journal of Procurement Management, 10(5), 539-554. https://doi.org/10.1504/IJPM. 2017.086399

Turskis, Z., \& Zavadskas, E. K. (2010a). A new fuzzy additive ratio assessment method (ARAS-F). Case study: The analysis of fuzzy multiple criteria in order to select the logistic centers location. Transport, 25(4), 423-432. https://doi.org/10.3846/transport.2010.52

Turskis, Z., \& Zavadskas, E. K. (2010b). A novel method for multiple criteria analysis: grey additive ratio assessment (ARAS-G) method. Informatica, 21(4), 597-610. 
Turskis, Z., Lazauskas, M., \& Zavadskas, E. K. (2012). Fuzzy multiple criteria assessment of construction site alternatives for non-hazardous waste incineration plant in Vilnius city, applying ARAS-F and AHP methods. Journal of Environmental Engineering and Landscape Management, 20(2), 110-120. https://doi.org/10.3846/164 86897.2011 .645827

Turskis, Z., Zavadskas, E. K., Antucheviciene, J., \& Kosareva, N. (2015). A hybrid model based on fuzzy AHP and fuzzy WASPAS for construction site selection. International Journal of Computers Communications \& Control, 10(6), 113128. https://doi.org/10.15837/ijccc.2015.6.2078

Turskis, Z., \& Juodagalviene, B. (2016). A novel hybrid multi-criteria decision-making model to assess a stairs shape for dwelling houses. Journal of Civil Engineering and Management, 22(8), 1078-1087. https://doi.org/10.3846/139 23730.2016 .1259179

Turskis, Z., Dzitac, S., Stankiuviene, A., \& Sukys, R. (2019). A Fuzzy Group Decision-making Model for Determining the Most Influential Persons in the Sustainable Prevention of Accidents in the Construction SMEs. International Journal of Computers, Communications \& Control, 14(1), 90-106. https://doi.org/10.15837/ijccc.2019.1.3364

Ulutas, A., Shukla, N., Kiridena, S., \& Gibson, P. (2016). A utility-driven approach to supplier evaluation and selection: empirical validation of an integrated solution framework. International Journal of Production Research, 54(5), 15541567. https://doi.org/10.1080/00207543.2015.1098787

Van Laarhoven, P. J. M., \& Pedrycz, W. (1983). A fuzzy extension of Saaty's priority theory. Fuzzy Sets and Systems, 11(13), 229-241. https://doi.org/10.1016/S0165-0114(83)80082-7

Vargas, L. G. (1990). An overview of the analytic hierarchy process and its applications. European Journal of Operational Research, 48(1), 2-8. https://doi.org/10.1016/0377-2217(90)90056-H

Wang, Y. M., \& Elhag, T. M. (2007). A fuzzy group decision making approach for bridge risk assessment. Computers \& Industrial Engineering, 53(1), 137-148. https://doi.org/10.1016/j.cie.2007.04.009

Wang, Y. M., Luo, Y., \& Hua, Z. (2008). On the extent analysis method for fuzzy AHP and its applications. European Journal of Operational Research, 186(2), 735-747. https://doi.org/10.1016/j.ejor.2007.01.050

Wang Chen, H. M., Chou, S. Y., Luu, Q. D., \& Yu, T. H. K. (2016). A fuzzy MCDM approach for green supplier selection from the economic and environmental aspects. Mathematical Problems in Engineering, 2016. https://doi.org/10. $1155 / 2016 / 8097386$

Wang, C. N., Nguyen, V. T., Thai, H. T. N., Tran, N. N., \& Tran, T. L. A. (2018). Sustainable Supplier Selection Process in Edible Oil Production by a Hybrid Fuzzy Analytical Hierarchy Process and Green Data Envelopment Analysis for the SMEs Food Processing Industry. Mathematics, 6(12), 302. https://doi.org/10.3390/math6120302

Wu, W. W., \& Lee, Y. T. (2007). Developing global managers' competencies using the fuzzy DEMATEL method. Expert Systems with Applications, 32(2), 499-507. https://doi.org/10.1016/j.eswa.2005.12.005

Xu, Z., \& Liao, H. (2014). Intuitionistic fuzzy analytic hierarchy process. IEEE Transactions on Fuzzy Systems, 22(4), 749_ 761. https://doi.org/10.1109/TFUZZ.2013.2272585

Yadav, V., \& Sharma, M. K. (2015). Multi-criteria decision making for supplier selection using fuzzy AHP approach. Benchmarking: An International Journal, 22(6), 1158-1174. https://doi.org/10.1108/BIJ-04-2014-0036

Yazdani, M., Zarate, P., Kazimieras Zavadskas, E., \& Turskis, Z. (2019). A Combined Compromise Solution (CoCoSo) method for multi-criteria decision-making problems. Management Decision, 57(9), 2501-2519. https://doi.org/10. 1108/MD-05-2017-0458

You, X. Y., You, J. X., Liu, H. C., \& Zhen, L. (2015). Group multi-criteria supplier selection using an extended VIKOR method with interval 2-tuple linguistic information. Expert Systems with Applications, 42(4), $1906-1916$. https://doi.org/10.1016/j.eswa.2014.10.004

Zahedi, F. (1986). The analytic hierarchy process-a survey of the method and its applications. Interfaces, 16(4), 96-108. https://doi.org/10.1287/inte.16.4.96

Zavadskas, E. K. \& Kaklauskas, A. 1996. Determination of an efficient contractor by using the new method of multicriteria assessment. In Langford, D. A.; Retik, A. (Eds.) International Symposium for "The Organisation and Management of Construction". Shaping Theory and Practice2: Managing the Construction Project and Managing Risk. CIB W 65; London, Weinheim, New York, Tokyo, Melbourne, Madras. - London: E and FN SPON: 94-104.

Zavadskas, E. K., Kaklauskas, A., Turskis, Z., \& Kalibatas, D. (2009). An approach to multi-attribute assessment of indoor environment before and after refurbishment of dwellings. Journal of Environmental Engineering and Landscape Management, 17(1), 5-11. https://doi.org/10.3846/1648-6897.2009.17.5-11

Zavadskas, E. K., \& Turskis, Z. (2010). A new additive ratio assessment (ARAS) method in multicriteria decision-making. Technological and Economic Development of Economy, 16(2), 159-172. https://doi.org/10.3846/tede.2010.10 
Zavadskas, E. K., Turskis, Z., Antucheviciene, J., \& Zakarevicius, A. (2012). Optimization of weighted aggregated sum product assessment. Elektronika ir Elektrotechnika, 122(6), 3-6. https://doi.org/10.5755/j01.eee.122.6.1810

Zavadskas, E. K., Turskis, Z., Volvaciovas, R., \& Kildiene, S. (2013). Multi-criteria assessment model of technologies. Studies in Informatics and Control, 22(4), 249-258. https://doi.org/10.24846/v22i4y201301

Zavadskas, E. K., Turskis, Z., \& Antucheviciene, J. (2015). Selecting a contractor by using a novel method for multiple attribute analysis: Weighted Aggregated Sum Product Assessment with grey values (WASPAS-G). Studies in Informatics and Control, 24(2), 141-150. https://doi.org/10.24846/v24i2y201502

Zavadskas, E. K., Govindan, K., Antucheviciene, J., \& Turskis, Z. (2016). Hybrid multiple criteria decision-making methods: A review of applications for sustainability issues. Economic Research-Ekonomska Istraživanja, 29(1), 857887. https://doi.org/10.1080/1331677X.2016.1237302

Zavadskas, E. K., Mardani, A., Turskis, Z., Jusoh, A., \& Nor, K. M. (2016). Development of TOPSIS method to solve complicated decision-making problems - An overview on developments from 2000 to 2015. International Journal of Information Technology \& Decision Making, 15(03), 645-682. https://doi.org/10.1142/S0219622016300019

Zhao, J., You, X. Y., Liu, H. C., \& Wu, S. M. (2017). An extended VIKOR method using intuitionistic fuzzy sets and combination weights for supplier selection. Symmetry, 9(9), 169. https://doi.org/10.3390/sym9090169

Zimmer, K., Frohling, M., Breun, P., \& Schultmann, F. (2017). Assessing social risks of global supply chains: a quantitative analytical approach and its application to supplier selection in the German automotive industry. Journal of Cleaner Production, 149, 96-109. https://doi.org/10.1016/j.jclepro.2017.02.041

The article has been reviewed.

Received in April 2018; accepted in December 2019. 